Burden, A.; Garbutt, R.A.; Evans, C.D.; Jones, D.L.; Cooper, D.M. Carbon sequestration and biogeochemical cycling in a saltmarsh subject to coastal managed realignment.

Copyright @ 2013 Elsevier Ltd.

This version available http://nora.nerc.ac.uk/500314/

NERC has developed NORA to enable users to access research outputs wholly or partially funded by NERC. Copyright and other rights for material on this site are retained by the rights owners. Users should read the terms and conditions of use of this material at http://nora.nerc.ac.uk/policies.html\#access

NOTICE: this is the author's version of a work that was accepted for publication in Estuarine, Coastal and Shelf Science. Changes resulting from the publishing process, such as peer review, editing, corrections, structural formatting, and other quality control mechanisms may not be reflected in this document. Changes may have been made to this work since it was submitted for publication. A definitive version was subsequently published in Estuarine, Coastal and Shelf Science (2013), 120. 12-20. 10.1016/i.ecss.2013.01.014

\title{
www.elsevier.com/
}

Contact CEH NORA team at noraceh@ceh.ac.uk

The NERC and CEH trademarks and logos ('the Trademarks') are registered trademarks of NERC in the UK and other countries, and may not be used without the prior written consent of the Trademark owner. 


\section{Carbon sequestration and biogeochemical cycling in a saltmarsh subject to coastal managed}

2 realignment

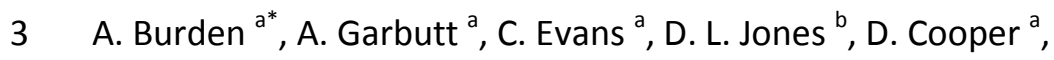

$4 \quad{ }^{a}$ Centre for Ecology and Hydrology, Environment Centre Wales, Deiniol Road, Bangor, Gwynedd, LL57

$52 U W, U K$

$6{ }^{\mathrm{b}}$ School of the Environment, Natural Resources \& Geography, Bangor University, Bangor, Gwynedd,

$7 \quad$ LL57 2UW, UK

8 * Corresponding author: Email: anrd@ceh.ac.uk; Phone: +44 (0) 1248374537 ; Fax: +44 (0) 1248

9362133

10 Keywords: saltmarsh; carbon sequestration; organic matter cycling; nutrient cycles; managed

11 realignment

12 Regional index terms: UK, east coast, Tollesbury

13 Abstract

14 Globally, wetlands provide the largest terrestrial carbon (C) store, and restoration of degraded wetlands provides a potentially important mechanism for climate change mitigation. We examined the potential for restored saltmarshes to sequester carbon, and found that they can provide a modest, but sustained, sink for atmospheric $\mathrm{CO}_{2}$. Rates of $\mathrm{C}$ and nutrient cycling were measured and compared between a natural saltmarsh (high- and low-shore locations), claimed arable land on former high-shore saltmarsh and a managed realignment restoration site (high- and low-shore) in transition from agricultural land to saltmarsh 15 years after realignment, at Tollesbury, Essex, UK. We measured pools and turnover of $\mathrm{C}$ and nitrogen $(\mathrm{N})$ in soil and vegetation at each site using a range of methods, including gas flux measurement and isotopic labelling. The natural high-shore site had the highest soil organic matter concentrations, topsoil C stock and below-ground biomass, whereas the agricultural site had the highest total extractable $\mathrm{N}$ concentration and lowest soil $\mathrm{C} / \mathrm{N}$ ratio. Ecosystem respiration rates were similar across all three high-shore sites, but much higher in both low-shore sites, which receive regular inputs of organic matter and nutrients from the estuary. 
27 Total evolution of ${ }^{14} \mathrm{C}$-isotopically labelled substrate as $\mathrm{CO}_{2}$ was highest at the agricultural site, suggesting that low observed respiration rates here were due to low substrate supply (following a recent harvest) rather than to inherently low microbial activity. The results suggest that, after 15 years, the managed realignment site is not fully equivalent to the natural saltmarsh in terms of biological and chemical function. While above ground biomass, extractable $\mathrm{N}$ and substrate mineralisation rates in the high-shore site were all quite similar to the natural site, less dynamic ecosystem properties including soil $\mathrm{C}$ stock, $\mathrm{C} / \mathrm{N}$ ratio and below-ground biomass all remained more similar to the agricultural site. These results suggest that reversion to natural biogeochemical functioning will occur following restoration, but is likely to be slow; we estimate that it will take approximately 100 years for the restored site to accumulate the amount of $\mathrm{C}$ currently stored in the natural site, at a rate of $0.92 \mathrm{t} \mathrm{Cha}^{-1} \mathrm{yr}^{-1}$.

\section{Introduction}

Globally, wetlands provide the largest terrestrial carbon stores, and restoration of degraded wetlands provides a potentially important mechanism for climate change mitigation. To date, much research has focused on restoring degraded peatlands, for example through re-wetting. However, this research has highlighted uncertainties regarding its overall impact on $\mathrm{C}$ and greenhouse gas balances, due to the potential for enhanced release of $\mathrm{CH}_{4}$ following re-wetting (Strack et al., 2004; Baird et al., 2009). There is an increasing in the potential for restored coastal wetland systems to sequester large amounts of carbon (Craft et al., 2003; Shepherd et al., 2007; Santin et al., 2009; Livesley and Andrusiak, 2012). Additionally, restoring coastal wetlands may avoid the offsetting effects of enhanced methane production associated with peat re-wetting, due to the presence of sulphates which allows sulphate-reducing bacteria to outcompete methanogens for energy sources (Poffenbarger et al., 2011; Bartlett et al., 1987; Andrews et al., 2006). Therefore, per unit area, restoration of coastal wetlands such as saltmarshes may contribute more to $\mathrm{C}$ sequestration, and therefore to climate regulation, than peatlands. However, at present, evidence is sparse. 
As well as carbon sequestration, saltmarshes provide a range of other ecosystem services.

These include immobilisation of pollutants (e.g. retention of diffuse nutrient and faecal pollutants into accumulating sediments), flood defence and shore line erosion control and they are a significant reservoir of wild species diversity (Jones et al., 2011). However historically, human activity has focused on the land-claim ('reclamation') of saltmarsh for agriculture, and more recently for port development leading to an estimate by French (1997) that $25 \%$ of the world's intertidal estuarine habitat had been lost due to land claim. Accelerated sea-level rise also poses a threat to existing saltmarsh through coastal squeeze, as sea defences restrict their natural landward migration to higher elevation (Blackwell et al., 2004). Globally, efforts are now being made to restore and create saltmarshes to mitigate historic losses and on-going development. Since the early 1990s, the driving force for restoration was the unsustainable increasing cost of maintaining and upgrading existing sea defences (Andrews et al., 2006). However, managed realignment is also undertaken for purposes of habitat or biodiversity enhancement or restoration, for example in Europe, salt-marsh restoration allows government compliance with the European Union Habitats Directive (C.E.G., 1992) which states there should be 'no further net loss of coastal marsh' (UK Biodiversity Group, 1999). UK targets aim to create 2240 ha of saltmarsh between 1999 and 2015, primarily via a process known as 'managed realignment'; the landward retreat of coastal defences and subsequent tidal inundation of previously-claimed agricultural land (Garbutt et al., 2006).

In general, managed realignment schemes in the UK and elsewhere have shown that, with relatively minimal pre-treatment and/or management of the area, allowing tidal ingress through a breach of the existing seawall onto low-lying agricultural land will quickly produce intertidal mudflats that are colonised by saltmarsh plants (French et al., 2000; Wolters et al., 2005). Managed realignment sites are sinks of sediment and, given time, representative saltmarsh plant, invertebrate and bird communities can become established (Garbutt et al., 2006). Newly created saltmarsh also acts as a natural sea defence by attenuating tidal amplitude (Pethick, 2002). Self-sustaining plant communities are often the primary goal of restoration efforts as they perform some of the desirable 
functions of wetland ecosystems (Craft et al., 2002; Möller et al., 1999; van Andel, 1998). However, many physical and functional processes such as nutrient cycling in these sites are poorly understood, and it has yet to be shown that restored saltmarshes are functionally equivalent to referenced systems and therefore whether they do effectively compensate for the loss of habitat as intended. In particular, the capacity of managed realignment schemes to accumulate carbon following conversion from agricultural land to saltmarsh has not been fully quantified.

This study measures and compares biogeochemical functioning between a 15 year old managed realignment site in a state of transition from agricultural land to saltmarsh, relative to adjacent areas of natural saltmarsh and arable land on former saltmarsh. Our three main objectives were: 1) to compare general soil characteristics between the restored saltmarsh, natural saltmarsh and agricultural sites; 2 ) to quantify and compare the organic matter, carbon and nitrogen pools at all sites, and estimate how far soil carbon stocks at the restored site have progressed along a trajectory between its former agricultural condition and the natural saltmarsh; 3 ) to investigate potential differences in the dynamics of organic matter cycling by measuring in situ ecosystem respiration and carbon mineralisation rates.

\section{Materials and methods}

\subsection{Site description}

This study was undertaken at the Tollesbury managed realignment site, adjacent natural marshes and arable land of the Blackwater Estuary, south-east England ( $51^{\circ} 46^{\prime} \mathrm{N}, 0^{\circ} 51^{\prime} \mathrm{E}$, Fig. 1$)$ in July 2010. The 21-ha restoration site had originally been a saltmarsh, but was claimed for agriculture in the late 18th century (Boorman et al., 1997). The sea defences were breached in August 1995, leaving a 50$\mathrm{m}$ wide opening and allowing tidal ingress to the site for the first time in over 150 years. The construction of a new sea defence landward of the old embankment prevented tidal flooding of the neighbouring arable fields which were claimed from saltmarsh at the same time as the managed realignment site. The altitude of the site ranges from $0.9 \mathrm{~m}$ to $3.0 \mathrm{~m}$ above Ordnance Datum (OD), with the major part of the site lying below $2.0 \mathrm{~m}$ OD (Garbutt et al., 2006). Mean high water neap 
(MHWN) and mean high water spring (MHWS) tide levels for the Blackwater estuary are $1.50 \mathrm{~m}$ and $2.60 \mathrm{~m}$ OD, respectively (Pye and French, 1993). There are two dominant plant communities within the managed realignment site. Above $1.75 \mathrm{~m}$ the upper part of the site (referred to as 'restored high') is dominated by a species poor Puccinellia maritima dominated community with occasional Atriplex portulacoides, Spergularia media and Suaeda maritima. At the same elevation on the adjacent natural saltmarshes (referred to as 'natural high') the plant communities are characterised by a diverse mix of saltmarsh plant species with abundant Limonium vulgare and P. maritima, frequent Salicornia europaea agg. and Sarcocornia perennis and occasional Armeria vulgare, A. portulacoides, S. maritima and Triglochin maritima. Below $1.75 \mathrm{~m}$ the lower part of the site (referred to as 'restored low') is dominated by Spartina anglica and abundant S. europaea agg. At the same elevation on the adjacent natural saltmarshes (referred to as 'natural low') the plant communities are dominated by S. europaea agg. with occasional S. maritima. Landward of the managed realignment site land claimed from saltmarsh in the 1800s is farmed for wheat (Triticum aestivum) and other crops.

\subsection{Experimental design}

Two different elevations (2.5 and $1.75 \mathrm{~m}$ above OD) within the managed realignment site were chosen to best represent the dominant plant communities as described above. The equivalent elevations on the adjacent marshes were determined through a topographic survey. Elevation was used as a surrogate for tidal inundation to ensure that the plant communities within the deembankment sites and reference marshes received equivalent submergence frequencies, and was checked by observing the depth and extent of the incoming tide for each site. No visual differences were observed. At the time of survey, the wheat crop had been harvested from the agricultural land adjacent to the site, however, the soil had not been tilled for subsequent crops and stubble remained at the surface.

A split-plot experimental design was used with six locations sampled at each site location. 
low shore sites. The six sampling locations at each site were in two clusters of three, with the two clusters separated by $150 \mathrm{~m}$ and within-cluster spacing of $10 \mathrm{~m}$. This arrangement provides an estimate of spatial variability (Fig. 1). With six sampling locations in two high shore, two low shore and one agricultural site, this gave 30 individual sample sites in all. Soil cores $(4 \mathrm{~cm}$ diameter by 30 $\mathrm{cm}$ depth) were taken from within the footprint of each of the greenhouse gas monitoring chambers (see below) after the third day of gas sampling. Each core was split into 3 sections $(0-10 \mathrm{~cm}, 10-20$ $\mathrm{cm}$ and $20-30 \mathrm{~cm}$ ) which were analysed separately. A second soil core was taken for below ground plant biomass measurements only. All field work took place in July 2010.

\subsection{Soil characteristics}

Electrical conductivity $(\mathrm{EC})$ and $\mathrm{pH}$ were measured in 1:1 (w/v) soil:distilled water extracts (Smith and Doran, 1996). Moisture content was determined by measuring the weight loss after drying the soil at $105^{\circ} \mathrm{C}$ overnight. Organic matter content was determined as the percent weight loss after ignition overnight at $375^{\circ} \mathrm{C}$. Available ammonium $\left(\mathrm{NH}_{4}{ }^{+}\right)$and nitrate $\left(\mathrm{NO}_{3}{ }^{-}\right)$were determined in 1:5 (w/v) soil: $0.5 \mathrm{M} \mathrm{K}_{2} \mathrm{SO}_{4}$ extracts following the method described in Jones et al. (2005) and the colorimetric analysis procedures of Mulvaney (1996) and Miranda et al. (2001). Water soluble phosphorous $(P)$, sodium $(\mathrm{Na})$, potassium $(K)$ and calcium $(\mathrm{Ca})$ were determined using 1:5 $(\mathrm{w} / \mathrm{v})$ soil:distilled water extracts following shaking $(1 \mathrm{~h}$ ) and centrifugation (6000 $\mathrm{g}, 15 \mathrm{~min}$ ) to remove particulate material. P was determined colorimetrically using the molybdate blue/ascorbic acid procedure of Murphy and Riley (1962) while Na, K and Ca were determined with a PFP7 Flame Photometer (Jenway flame photometer (Bibby Scientific Ltd, Staffs, UK). Soluble humic substances in the water extracts were estimated by measuring the UV absorbance of the extracts at $254 \mathrm{~nm}$ (USEPA, 2005). Bulk density was measured using bulk density rings with a volume of $45.2 \mathrm{~cm}^{3}$. Samples combustion on a TruSpec CN Analyser (Leco Corp, St Joseph, MI). 
The soil carbon pool was estimated by multiplying the bulk density by the percentage carbon figures.

157 It was therefore only estimated for the surface of the soil where bulk density values were available. The restored high marsh per year increase in carbon was derived by taking the difference in the soil carbon pool between the agricultural and restored high shore sites and dividing by the number of years since managed realignment (i.e. 15 y). The estimate of how long it would take for the soil carbon pool of the restored high shore site to become equivalent to the natural high shore site was calculated by dividing the difference between the agricultural and natural high shore site soil carbon pool by the per year increase of the restored high shore site, assuming that this was equivalent to the agricultural site pre-restoration.

\subsection{Gas flux measurements}

Ecosystem $\mathrm{CO}_{2}, \mathrm{CH}_{4}$ and $\mathrm{N}_{2} \mathrm{O}$ emissions were measured using dark static chambers within two hours of high water. Gas sampling with the static chambers was carried out on 3 successive days to take account of temporal variability. Placement of the static chambers was marked with canes allowing return to the exact same position on consecutive days. On the first day both clusters of 3 at each land use/elevation combination were sampled giving 30 sample locations in total. On days two and three only one cluster of each land use/elevation combination was sampled, giving 15 sample locations on the second and third days. After placement of the chambers on the soil surface, gas samples were taken with a syringe from each chamber after $0,15,30,45$ and 60 minutes, injected into evacuated gas chromatograph vials and analysed within one week. In addition to these samples, duplicate samples were taken from one chamber for each treatment to test reproducibility. All gas samples were analysed using a Perkin Elmer Clarus 500 Gas Chromatograph (GC) equipped with a Porapaq QS (80-100 mesh) analytical column and turbomatrix 40 headspace auto analyser. $\mathrm{N}_{2} \mathrm{O}$ was detected using an electron capture detector (ECD) at $400^{\circ} \mathrm{C}$, sample oven at $40^{\circ} \mathrm{C} ; \mathrm{CH}_{4}$ was detected using a flame ionisation detector (FID) at $375^{\circ} \mathrm{C}$, sample oven at $40^{\circ} \mathrm{C}$ equipped with a methaniser. Carrier gas pressure was $138 \mathrm{kPa}$, and injection pressure $160 \mathrm{kPa}$, all other controls were as Perkin 

points throughout each sample run. Gas fluxes were then calculated on an hourly basis using the following calculations:

$$
C m=(C v \times M \times P) /(R \times T)
$$

where $\mathrm{Cm}$ is the mass per volume (expressed as $\mathrm{mg} \mathrm{m}^{-3}$ ), $\mathrm{Cv}$ is the gas concentration (expressed as pressure, $T$ is the chamber temperature in Kelvin $\left({ }^{\circ} \mathrm{C}+273.15\right)$ at time of sample, and $R$ is the gas constant.

The per hour flux $\left(F, \mathrm{mg} \mathrm{m}^{-2} \mathrm{~h}^{-1}\right)$ was then calculated by:

where $V$ is the internal volume of the enclosure including collar volume (expressed as $\mathrm{m}^{3}$ ), $A$ is the area of the collar enclosed surface $\left(\mathrm{m}^{2}\right), C_{\text {rate }}$ is the change in gas concentration (i.e. $\mathrm{Cm} \mathrm{t}_{1}-\mathrm{Cm} \mathrm{t}_{0}$ ) over the enclosure period.

\subsection{Carbon substrate mineralisation}

$\mathrm{A}^{14} \mathrm{C}$-isotopically labelled $\mathrm{C}$ substrate was used to estimate carbon mineralisation rates in soil as described in Simfukwe et al. (2011). The C substrate consisted of ${ }^{14} \mathrm{C}$-labelled shoots of Lolium perenne (L.) with a specific activity of $12.3 \mathrm{kBq} \mathrm{g}^{-1}$. The ${ }^{14} \mathrm{C}$-enrichment of Lolium perenne plant material was performed by pulse labelling with ${ }^{14} \mathrm{CO}_{2}$ at a constant specific activity according to Hill et al. (2007). To characterise the ${ }^{14} \mathrm{C}$ label in the plant material, a sequential chemical fractionation was performed according to Jones and Darrah (1994). Briefly, $50 \mathrm{mg}$ of finely ground plant material was sequentially extracted in $8 \mathrm{ml}$ deionised water for $30 \mathrm{~min}$ at $85^{\circ} \mathrm{C}, 8 \mathrm{ml} 20 \%$ ethanol for $30 \mathrm{~min}$ at $80{ }^{\circ} \mathrm{C}, 5 \mathrm{ml} 0.3 \% \mathrm{HCl}$ for $3 \mathrm{~h}$ at $95^{\circ} \mathrm{C}$ and $5 \mathrm{ml} 1 \mathrm{M} \mathrm{NaOH}$ for $1 \mathrm{~h}$ at $95^{\circ} \mathrm{C}$. After each extraction step, the sample was centrifuged $(5000 \mathrm{~g}, 15 \mathrm{~min})$, the supernatant removed and its ${ }^{14} \mathrm{C}$ content determined using Optiphase $3^{\circ}$ Scintillation fluid (PerkinElmer, Waltham, MA) and a Wallac 1404 Liquid Scintillation Counter (PerkinElmer Corp., Waltham, MA). For each soil, $10 \mathrm{~g}$ was placed into a sterile $50 \mathrm{~cm}^{3}$ polypropylene container and $100 \mathrm{mg}$ of the ${ }^{14} \mathrm{C}$-labelled complex $\mathrm{C}$ substrate was then 
added to the soil. A vial containing $1 \mathrm{M} \mathrm{NaOH}$ was then placed above the soil and the polypropylene containers hermetically sealed. The ${ }^{14} \mathrm{CO}_{2}$ capture efficiency of the $\mathrm{NaOH}$ traps was $>95 \%$. The soils were then placed in the dark in a climate-controlled room $\left(10^{\circ} \mathrm{C}\right)$ and the $\mathrm{NaOH}$ traps exchanged every 3 days for 24 days. The ${ }^{14} \mathrm{CO}_{2}$ in the $\mathrm{NaOH}$ traps was determined by liquid scintillation counting as described above.

Of the total ${ }^{14} \mathrm{C}$ contained in the plant material and subsequently added to soil, $32.9 \pm 1.5 \%$ was extractable by water, $4.2 \pm 0.2 \%$ by ethanol, $16.8 \pm 0.6 \%$ by HCl, $27.5 \pm 0.4 \%$ by $\mathrm{NaOH}$ and $18.5 \pm$ $2.2 \%$ was insoluble residue. These components approximately correspond to the readily decomposable or neutral-detergent soluble $\mathrm{C}$ (water and ethanol soluble), cellulose and hemicellulose ( $\mathrm{HCl}$ soluble) and lignin ( $\mathrm{NaOH}$ soluble and insoluble) fractions of organic matter respectively (Domisch et al., 1998; Ekschmitt et al., 2008; Moorhead and Sinsabaugh, 2006).

\subsection{Statistical analysis}

A linear mixed effects model (Ime) was used to describe the data using R version 2.13.2 (y Site*Depth,random= 1|Location/sample). We also fitted models excluding respectively the depth and site effects to test the need for their inclusion in the model. On all but one occasion both regime and depth were significant $(p<0.05)$, confirming the need for both fixed effects to be included. For each variable we also tested for the significance of differences between each regime and depth pair. Separate analyses by depth and by regime were also carried out. A similar approach was taken for the gas measurements replacing 'depth' with 'day' in the analysis. As there was no significant difference in gas measurements between days within sites, the average flux over the 3 days of measurement was analysed. For the carbon substrate mineralisation, the final data points were used in the Ime model (i.e. total evolution of ${ }^{14} \mathrm{CO}_{2}$ within incubation period of 25 days expressed as $\%$ of ${ }^{14} \mathrm{C}$-substrate added to the soil). This approach enabled the raw data to be analysed accounting for replication at the level of the experimental unit or site $(n=5)$. For analysis we used the $\log _{10}$ of all variables other than $\mathrm{pH}$. 


\section{Results and discussion}

\subsection{General soil characteristics}

There were significant differences $(p<0.05)$ between sites in all of the soil properties measured. Soil conductivity was highest at the natural high shore marsh, lowest at the agricultural site, and intermediate at the restored high shore site (averages of $12.08,0.14$ and $4.40 \mathrm{mS} \mathrm{cm}^{-1}$ respectively, Table 1). These large differences highlight the influence of seawater on both the natural and restored sites, and of freshwater on the agricultural site. There was no significant difference between the restored and natural low shore sites $(p=0.582)$ and all sites showed a decrease in conductivity with depth. The sodium, potassium and calcium data, as would be expected, reflected the differences observed in the conductivity data - they were all significantly $(p \leq 0.009)$ higher at the natural high shore site and lowest at the agricultural site $(p \leq 0.010$, Table 1$)$.

\subsection{Plant biomass and soil organic matter, $\mathrm{C}$ and $\mathrm{N}$ pools}

The restored high shore site was found to have approximately twice as much above ground plant biomass compared to the natural high shore site $(p=0.037$, Fig. 2$)$ due to it being dominated by a monoculture of $P$. maritima. On the other hand, there was 16 times more below ground plant biomass in the natural high shore site than at any of the other sites sampled (average of $11.5 \mathrm{~kg} \mathrm{~m}^{-2}$ compared to $0.7 \mathrm{~kg} \mathrm{~m}^{-2}$ for the other four sites; Fig. 2) due to the species-rich vegetation consisting of long lived perennials with woody tap roots. This translated into the natural high shore site soil having significantly greater $(p<0.05)$ organic matter content (and therefore less mineral material) than all other sites at all three depths (average of $21.8 \%$ compared to an average of $5.2 \%$ for the other four sites, Table 1); this appears consistent with data collected from created Spartina alterniflora marshes along the North Carolina coast (Craft, 2000), which showed that macro-organic matter (MOM) content increased with age of the created marsh. The agricultural site had significantly lower $(p<0.05)$ soil organic matter content than all other sites at depth $0-10 \mathrm{~cm}(p \leq$ $0.004)$ but was not significantly different $(p<0.05)$ to the two restored sites at depths $10-20 \mathrm{~cm}$ and $20-30 \mathrm{~cm}$. This suggests that even after 15 years of inundation, soils below $10 \mathrm{~cm}$ depth retain 
properties characteristic of the agricultural soil - an idea also supported by Craft (2000) in constructed Spartina alterniflora saltmarshes in North Carolina. Spencer et al. (2008) found similar evidence within a restored site 8 years after managed realignment, and hypothesized that the relic land surface may have formed an aquaclude which prevents vertical soil water movement. This idea is further supported in the current study by the $\mathrm{pH}$ and humic substances data, which both increased with depth in the restored high shore site to values that were more comparable to the agricultural site than the natural high shore site (supplementary Table 1).

The natural and restored low shore sites had the lowest soil carbon pool (average of 13.7 and $10.9 \mathrm{~kg} \mathrm{~m}^{-3}$ respectively, Fig. 2 ) and were not significantly different from each other $(p=0.260)$. This is not surprising as the low shore sites are both inundated daily and are dominated by pioneer annual species. In contrast, the natural high marsh site had a significantly greater soil carbon pool than all other sites $\left(p \leq 0.016\right.$, average of $\left.31.1 \mathrm{~kg} \mathrm{~m}^{-3}\right)$, whilst the restored high shore and agricultural sites had a similar soil carbon pool $(p=0.621)$ of 22.1 and $20.7 \mathrm{~kg} \mathrm{~m}^{-3}$ respectively (Fig. 2 ). This suggests that there has been, at best, only a small overall increase in the soil carbon pool of the restored high-shore site in the 15 years since managed realignment, and that the site is thus likely to take many more years to accumulate an equivalent carbon store to the natural system. Assuming that the restored high site previously resembled the agricultural site (see methods), the estimated rate of carbon accumulated at the Tollesbury managed realignment site was calculated to be $92.4 \mathrm{~g} \mathrm{C} \mathrm{m}^{-3} \mathrm{yr}^{-1}$, or $0.92 \mathrm{t} \mathrm{C} \mathrm{ha}^{-1} \mathrm{yr}^{-1}$. This is within the estimated UK saltmarsh carbon sequestration range of $0.64-2.19 \mathrm{t} \mathrm{Cha}^{-1} \mathrm{yr}^{-1}$ proposed by Cannell et al. (1999). We therefore estimate that it would take approximately 100 years for the restored site to accumulate the amount of carbon currently stored in the natural site. This is similar to the figure estimated by Craft et al. (2003) of up to 70 years for the total organic carbon pool to become equivalent to natural within a created S. alterniflora marsh. The 100 year estimate also corresponds that of Crooks et al. (2002) for the length of time it could take vegetation in realignment sites to resemble that of natural marshes, which (as noted above) has a substantial influence on the size of the soil organic matter 
pool. It has been suggested, however, that the organic matter formed in constructed marshes contains a greater proportion of labile organic compounds (Craft et al., 2003) which are turned over more quickly by the microbial community and could result in constructed or restored wetlands being less effective at sequestering carbon over time; this is considered further below. slowly transitioning towards the soil conditions currently observed at the natural marsh. This accords with other terrestrial data that suggest it takes a very long time, even centuries, to reverse historic enrichment of nutrient poor pools. oxidised N, Table 1) was 2.5 times higher than at any of the other sites, and significantly higher ( $p<$ 0.05 ) at all sites except the natural high shore site. This is indicative of both nutrient enrichment (wheat is cultivated at this site and is presumably fertilised) and aerobic conditions, both of which favour nitrification and therefore increased nitrate versus ammonium concentrations. In contrast, ammonium concentrations were at least four times higher at all other sites when compared to the agricultural site, and ammonium was the dominant form of mineral $\mathrm{N}$ at the natural high, managed high and managed low sites. These data suggest that managed realignment, which has led to the reinstatement of anaerobic soil conditions that promote denitrification and leaching, has resulted in rapid decreases in extractable nitrate levels. On the other hand, the presence of extractable ammonium in all samples from all these sites $\left(0.27-0.92 \mathrm{mg} \mathrm{kg}^{-1} \mathrm{dry}\right.$ weight, Table 1$)$ suggests a continued supply of mineral $\mathrm{N}$ via organic matter mineralisation in both natural and restored conditions, consistent with the relatively low measured $\mathrm{C} / \mathrm{N}$ ratios of soil organic matter (Table 1 ). The fact that ammonium concentrations were not significantly higher in the restored high shore site compared to the natural high site suggests that, despite soil $\mathrm{C} / \mathrm{N}$ remaining lower in the restored 
site, $\mathrm{N}$ mineralisation rates (and therefore nutrient $\mathrm{N}$ supply) may have returned to pre-agricultural levels following managed realignment.

\subsection{Dynamics of organic matter cycling}

$\mathrm{CH}_{4}$ and $\mathrm{N}_{2} \mathrm{O}$ fluxes were near-zero for all sites and on all sampling occasions, with concentrations at or close to ambient air concentrations (Table 2) - a result reflecting those of Livesley and Andrusiak (2012) who found that $\mathrm{CH}_{4}$ and $\mathrm{N}_{2} \mathrm{O}$ fluxes were close to zero in temperate saltmarsh in south eastern Australia. No significant between-site differences were observed. $\mathrm{CH}_{4}$ production is known to be inhibited by the presence of sulphate (e.g. from seawater), due to competition between sulphate reducing bacteria and methanogens (Bartlett et al., 1987; Andrews et al., 2006). Poffenbarger et al. (2011) proposed that the salinity regime required for methane flux to be negligible was $18 \mu \mathrm{gl}^{-1}$ - well within the expected range of salinity at Tollesbury. However, a similar study of a restored saltmarsh in the estuary of the River Torridge, Devon, UK, 6 months after managed realignment, concluded that managed realignment could result in increased production of $\mathrm{N}_{2} \mathrm{O}$, due the combination of high residual soil nitrogen levels from the agricultural site, and the reinstatement of dry-wet cycles following tidal reconnection (Blackwell et al., 2010). The River Torridge experiment was laboratory-based, and measured fluxes over simulated tidal cycles, which may explain the difference in results (an average of $0.65 \mathrm{mg} \mathrm{N}_{2} \mathrm{O}-\mathrm{N} \mathrm{m}^{-2} \mathrm{~h}^{-1}$ compared to zero in our study). However, if tidal pumping - tidal forcing of seawater into the coastal aquifer - does in fact flush $\mathrm{CO}_{2}$ and other carbon forms out of re-flooded soils (an idea proposed by Kathilankal et al., 2008) then our results should demonstrate maximum gaseous flux as they were taken within two hours prior to high tide. Given the limited number of sampling occasions, we cannot draw clear production rates, with the highest fluxes recorded for the restored low shore site, followed by the natural low shore site (Fig. 3). Overall, between-site differences were significant $(p<0.001)$ 
suggesting that both of the low shore sites were more microbially active, turning over carbon inputs at a higher rate than either of the high shore sites. The natural high shore site had the lowest $\mathrm{CO}_{2}$ flux but was not significantly lower than the restored high shore or agricultural site $(p \geq 0.3)$ suggesting that rates of carbon cycling among these three sites were similar. There was some indication however of an inverse relationship between $R_{\text {eco }}$ and $\mathrm{C} / \mathrm{N}$ for these three sites, consistent with higher rates of carbon turnover at the more nutrient-rich agricultural site. It is likely that lower $R_{\text {eco }}$ values at the agricultural site relative to the low shore sites are a consequence of reduced substrate supply following the harvesting of the crop (see below). Based on our measurements, we did not detect a clear influence of substrate quality on respiration rates, as suggested by Craft et al. (2003), although we acknowledge that the dataset only covers a short time-period. substrate added to the soil) was highest at the agricultural site (Fig. 4). This result contrasts with the low measured ecosystem respiration flux but, as noted above, the respiration measurements occurred after crop harvesting at the site, when substrate inputs would have been very low. As well as the direct production of $\mathrm{CO}_{2}$ from plant respiration, the presence or absence of vegetation has been shown to significantly affect microbial activity in soils via the supply of litter inputs and root exudates for microbial respiration (Oburger and Jones, 2009). The observation that added substrate was rapidly respired at the agricultural site indicates that potential rates of microbial carbon turnover are higher than those observed at the time of sampling. consistently lower, and the restored high shore site was not significantly different to the natural high shore site ( $p=0.107$, Fig. 4). As the added substrate was of high molecular weight carbon, results should provide an insight into differences in carbon sequestration potential between sites, on the basis that this material has the potential to be retained in the soil rather than respired, whereas low molecular weight fractions would likely be utilised by the microbial community in all sites. The results suggest an overall slower turnover rate, and therefore greater carbon storage potential, in 
the natural site, when compared to the agricultural soil. The absence of a significant difference in turnover rates between natural and restored high shore sites further suggests that, 15 years postrestoration, rates of carbon sequestration at the Tollesbury managed realignment site have now returned to those characteristic of the natural marsh.

At both low shore sites, measured substrate utilisation rates were higher than at the natural and restored high shore (significantly different at $p<0.05$ for all combinations other than the restored high versus natural low sites, $p=0.218$, Fig. 4 ), but lower than at the agricultural site. Higher substrate utilisation rates at the low versus high shore natural and restored sites are consistent with the ecosystem respiration measurements, again suggesting faster carbon turnover rates at these sites. Higher extractable nitrate and phosphate, and lower soil $\mathrm{C} / \mathrm{N}$ ratios, further suggest that this rapid turnover is linked to higher nutrient availability, possibly due to tidal recharge of nutrients.

\section{Conclusions}

In the UK, managed realignment is primarily undertaken for purposes of habitat and biodiversity enhancement or restoration, or for coastal defence. Carbon and nutrient cycling are rarely considered when these schemes are developed and monitored, let alone used as success criteria (which currently only consider vegetation development). However, with a growing policy emphasis on the wider ecosystem service implications of land-management, it is clear that enhanced carbon sequestration could provide an additional benefit resulting from restoration, whilst reversion of the nitrogen cycle to the low-nutrient levels characteristic of natural ecosystems may be a prerequisite for full vegetation recovery. Our data suggest that managed realignment reduces nitrogen mineralisation rates towards those of natural saltmarsh levels, but that soil $\mathrm{C} / \mathrm{N}$ ratios remain well below those of the natural site, suggesting that complete recovery to natural conditions may be far slower. Similarly, the soil carbon pool of the restored site was more similar to the agricultural site than the natural marsh, suggesting that there has been at best only a small overall increase in the carbon pool of the restored high-shore site in the 15 years since managed realignment. On the other 
hand, carbon mineralisation rates at the restored site were similar to the natural site, and lower

than the agricultural site, suggesting that the soil carbon pool of the restored site will ultimately converge with that of the natural marsh. Our calculations predict that this will take approximately 100 years.

\section{Acknowledgements}

The authors would like to thank Sarah Hodgson for soil quality assessment analysis, Stephanie Ellis for the mineralisation analysis and Marc Brouard for LOI, biomass and bulk density analysis. Also our

thanks go to Philip Stickler and David Watson (Cartographic Unit, Department of Geography,

University of Cambridge) who assisted with the production of figure 1.

397

398

399

400

401

402

403

404

405

406

407

408

409

410

411

412

\section{References}

Andrews, J. E., Burgess, D., Cave, R. R., Coombes, E. G., Jickells T. D., Parkes, D. J., Turner, R. K., 2006. Biogeochemical value of managed realignment, Humber estuary, UK. Science of the Total Environment 371, 19-30.

Baird, A., Holden, J., and Chapman, P., 2009. A Literature Review of Evidence on Emissions of Methane in Peatlands. Defra Project SP0574.

Bartlett, K.B., Bartlett, D.S., Harriss, R.C., Sebacher, D.I., 1987. Methane emissions along a salt-marsh salinity gradient. Biogeochemistry 4, 183-202.

Blackwell, M.S.A., Hogana, D.V., Maltbya, E., 2004. The short-term impact of managed realignment on soil environmental variables and hydrology. Estuarine, Coastal and Shelf Science 59, 687701.

Blackwell, M.S.A., Yamulki, S., Bol, R. 2010. Nitrous oxide production and denitrification rates in estuarine intertidal saltmarsh and managed realignment zones. Estuarine, Coastal and Shelf Science 87, 591-600.

Boorman, L.A., Garbutt, A., Barratt, D., Myhill, D., Eversham, B., Reading, C., Cox, R., Rothery, P. 1997. Large scale experimental managed realignment, vol. 1, Tollesbury, Essex. Institute of Terrestrial Ecology, Huntingdon. 
Cannell, M.G., Milne, R., Hargreaves, K.J., Brown, T.A., Cruickshank, M.M., Bradley, R.I., Spencer, T., Hope, D., Billett, M.F., Adger, W.N., Subak. S. 1999. National Inventories of Terrestrial Carbon Sources and Sinks: The UK Experience. Climate Change, 42, 505-530.

C.E.G., 1992. Council Directive 92/43/EEC of May 1992 on the Conservation of Natural Habitats and of Wild Fauna and Flora. Official Journal of the European Communities: L 206.

Crooks, S., Schutten, J., Sheern, G.D., Pye, K., Davy, A.J. 2002. Drainage and elevation as factors in the restoration of saltmarsh in Britain. Restoration Ecology 10, 591-602.

Craft, C. 2000. Co-development of wetland soils and benthic invertebrate communities following saltmarsh creation. Wetlands Ecology and Management 8, 197-207.

Craft, C., Broome, S., Campbell, C. 2002. Fifteen years of vegetation and soil development after Brackish-water marsh creation. Restoration Ecology 10, 248-258.

Craft, C., Megonigal, P., Broome, S., Stevenson, J., Freese, R., Cornell, J., Zheng, L., Sacco, J. 2003. The pace of ecosystem development of constructed Spartina alterniflora marshes. Ecological Applications 13, $1417-1432$.

Domisch, T., Finer, L., Karsisto, M., Laiho, R., Laine, J., 1998. Relocation of carbon from decaying litter in drained peat soils. Soil Biology \& Biochemistry 30, 1529-1536.

Ekschmitt, K., Kandeler, E., Poll, C., Brune, A., Buscot, F., Friedrich, M., Gleixner, G., Hartmann, A., Kästner, M., Marhan, S., Miltner, A., Scheu, S., and Wolters, V. 2008. Soil carbon preservation through habitat constraints and biological limitations on decomposer activity. Journal of Plant Nutrition and Soil Science 171, 27-35.

French, 1997 P.W. French, Coastal and Estuarine Management, Routledge, London (1997).

French, C.E., French, J.R., Clifford, N.J., Watson, C.J. 2000. Sedimentation-erosion dynamics of abandoned reclamations: the role of waves and tides. Continental Shelf Research 20, 17111733. 
Garbutt, R.A., Reading, C.J., Wolters, M., Gray, A.J., Rothery, P. 2006. Monitoring the development of intertidal habitats on former agricultural land after the managed realignment of coastal defences at Tollesbury, Essex, UK. Marine Pollution Bulletin 53, 155-164.

Hill, P. W., Marshall, C., Williams, G. G., Blum, H., Harmens, H., Jones, D. L. and Farrar, J. F. 2007. The fate of photosynthetically-fixed carbon in Lolium perenne grassland as modified by elevated $\mathrm{CO}_{2}$ and sward management. New Phytologist, 173, 766-777.

Jones, D.L., Darrah, P.R., 1994. Simple method for ${ }^{14} \mathrm{C}$ labelling root material for use in root decomposition studies. Communications in Soil Science and Plant Analysis 25, 2737-2743.

Jones, D.L., Kemmitt, S.J., Wright, D., Cuttle, S.P., Bol, R. and Edwards, A.C. 2005. Rapid intrinsic rates of amino acid biodegradation in soils are unaffected by agricultural management strategy. Soil Biology and Biochemistry 37, 1267-1275.

Jones, L., Angus, S., Cooper, A., Doody, P., Everard, M., Garbutt, A., Gilchrist, P., Hansom, J., Nicholls, P., Pye, K., Ravenscroft, N., Rees, S., Rhind, P., Whitehouse, A. 2011. Coastal Margins. In: The UK National Ecosystem Assessment Technical Report. UK National Ecosystem Assessment, UNEP-WCMC, Cambridge.

Kathilankal, J.C., Mozdzer, T.J., Fuentes, J.D., D’Odorico, P., McGlathery, K.J., Zieman, J.C. 2008. Tidal influences on carbon assimilation by a saltmarsh. Environmental research letters 3, 044010.

Livesley, S.M., Andrusiak, S.M. 2012. Temperate mangrove and saltmarsh sediments are a small methane and nitrous oxide source but important carbon store. Estuarine, Coastal and Shelf Science 97, 19-27.

Miranda, K.M., Espey, M.G., Wink, D.A. 2001. A rapid, simple spectrophotometric method for simultaneous detection of nitrate and nitrite. Nitric Oxide 5, 62-71.

Möller, I., Spencer, T., French, J.R., Leggett, D.J., Dixon, A.M. 1999. Wave transformation over saltmarshes: a field and numerical modelling study from North Norfolk, England. Estuarine, Coastal and Shelf Science 49, 411-426. 
Moorhead D.L, Sinsabaugh R.L. 2006. A theoretical model of litter decay and microbial interaction. Ecological Monographs 76(2), 151-174.

Mulvaney, R.L. 1996. Nitrogen-Inorganic Forms. In: Sparks, D.L. (Eds.), Methods of Soil Analysis: Chemical Methods. Part 3. Soil Science Society of America, Madison WI.

Murphy, J., Riley, J.P. 1962. A modified single solution method for the determination of phosphate in natural waters. Analytica Chimica Acta 27, 31-36.

Oburger, E., Jones, D.L. 2009. Substrate mineralization studies in the laboratory show different microbial C partitioning dynamics than in the field. Soil Biology and Biochemistry 41, 1951-

Pethick, J. S. 2002. Estuarine and tidal wetland restoration in the United Kingdom: policy versus practice. Restoration Ecology 10, 431-437

Poffenbarger, H.J., Needelman, B.A., Megonigal, J.P. 2011. Salinity influence on methane emissions from tidal marshes. Wetlands 31, 831-842.

Pye, K. and French, P.W. 1993. Erosion and accretion processes on British saltmarshes. Volume 2. Database of British saltmarshes. Final report to MAFF, ES19B(2). London.

R Development Core Team. 2011. R: A language and environment for statistical computing. $R$ Foundation for Statistical Computing, Vienna, Austria. ISBN 3-900051-07-0, URL http://www.R-project.org

Santín, C., de la Rosa, J.M., Knicker, H., Otero, X.L., Álvarez, M.A., González-Vila, F.J. 2009. Effects of reclamation and regeneration processes on organic matter from estuarine soils and sediments. Organic Geochemistry 40, 931-941.

Simfukwe, P., Hill, P.W., Emmett, B.A., Jones, D.L., 2011. Soil classification provides a poor indicator of carbon turnover rates in soil. Soil Biology \& Biochemistry 43, 1688-1696.

Shepherd, D., Burgess, D., Jickells, T., Andrews, J., Cave, R., Turner, R.K., Aldridge, J., Parker, E.R., Young, E. 2007. Modelling the effects and economics of managed realignment on the cycling 
and storage of nutrients, carbon and sediments in the Blackwater estuary UK. Estuarine, Coastal and Shelf Science 73, 355-367.

490

491

492

493

494

495

496

497

498

499

500

501

502

503

504

505

506

507

508

509

510

511

512

513

Smith, J.L., Doran, J.W. 1996. Measurement and use of $\mathrm{pH}$ and electrical conductivity for soil quality analysis. In: Doran, J.W., Jones, A.J. (Eds.), Methods for Assessing Soil Quality, Soil Sci. Soc. Am. Special Publication 49. Soil Science Society of America, Madison, WI.

Spencer, K.L., Cundy, A.B., Davies-Hearn, S., Hughes, R., Turner, S., MacLeod, C.L. 2008. Physicochemical changes in sediments at Orplands Farm, Essex, UK following 8 years of managed realignment. Estuarine, Coastal and Shelf Science 76, 608-619.

Strack, M., Waddington, J.M., Tuittila, E.S. 2004. Effect of water table drawdown on northern peatland methane dynamics: Implications for climate change. Global Biogeochemical Cycles 18, GB4003.

UK Biodiversity Group, 1999. UK Biodiversity Group: Tranche 2, Action Plans. Maritime Species and Habitats, vol. V, English Nature, Peterborough.

US-EPA, 2005. Determination of total organic carbon and specific UV absorbance at $254 \mathrm{~nm}$ in source water and drinking water. Method 415/3. EPA Document \#: EPA/600/R-05/055. US Environmental Protection Agency.

van Andel, J. 1998. Two approaches towards the relationship between plant species diversity and ecosystem functioning. Applied Vegetation Science 1, 9-14.

Wolters, M., Garbutt, A., Bakker, J.P. 2005. Salt-marsh restoration: evaluating the success of deembankments in northwest Europe. Biological Conservation 123, 249-268.

\section{(1)}

9


Fig. 1. Experimental design at the Tollesbury managed realignment site, adjacent natural marshes and arable land of the Blackwater Estuary, south-east England $\left(51^{\circ} 46^{\prime} \mathrm{N}, 0^{\circ} 51^{\prime} \mathrm{E}\right)$. Each circle represents one sampling location where three replicates were taken. Within replicate distances were $10 \mathrm{~m}$, and between sampling location distances were in the order of $150 \mathrm{~m}$. Open circles = high marsh, closed circles $=$ low marsh and grey circles $=$ agricultural.

530

Fig. 2. Above and below ground biomass and calculated soil carbon pool measured at all 5 sites. Values represent means \pm standard deviation. The site effect was evaluated using a linear mixed effects model, the $p$ value of which is displayed. Significant differences between site means are denoted by different letters.

Fig. 3. Ecosystem respiration $\left(R_{\text {eco }}\right)$ measured for all 5 sites. Values represent means \pm standard deviation. The site effect was evaluated using a linear mixed effects model, the $p$ value of which is displayed. Significant differences between site means are denoted by different letters. 
540 Fig. 4. Carbon mineralisation rates measured (as a $\%$ of total ${ }^{14} \mathrm{C}$-substrate added) for all 5 sites.

541 Values represent means \pm standard deviation. The site effect was evaluated using a linear mixed

542 effects model on the final data points (total evolution within incubation period of 25 days 543 expressed as $\%$ of ${ }^{14} \mathrm{C}$-substrate added to the soil), the $p$ value of which is displayed. Significant 544 differences between site means are denoted by different letters.

545

546

547

548

549

550 Table 1. Soil properties measured at all 5 sites. Site means $(n=18)$ are presented \pm standard

551 deviation. For bulk density $n=6$. The site effect was evaluated using a linear mixed effects model.

552 Significant differences $(p<0.05)$ between site means are denoted by different letters.

553

\begin{tabular}{|c|c|c|c|c|c|c|c|c|c|c|}
\hline & \multirow{2}{*}{\multicolumn{2}{|c|}{ Agricultural }} & \multirow{2}{*}{\multicolumn{2}{|c|}{$\begin{array}{c}\text { Restored } \\
\text { High }\end{array}$}} & \multirow{2}{*}{\multicolumn{2}{|c|}{$\begin{array}{c}\text { Natural } \\
\text { High }\end{array}$}} & \multirow{2}{*}{\multicolumn{2}{|c|}{$\begin{array}{c}\text { Restored } \\
\text { Low }\end{array}$}} & \multirow{2}{*}{\multicolumn{2}{|c|}{$\begin{array}{c}\text { Natural } \\
\text { Low }\end{array}$}} \\
\hline & & & & & & & & & & \\
\hline $\mathrm{pH}$ & $7.9 \pm 0.5$ & $b$ & $7.2 \pm 0.3$ & c & $6.4 \pm 0.2$ & $a$ & $7.6 \pm 0.3$ & $b c$ & $7.8 \pm 0.1$ & $b$ \\
\hline Soil conductivity (mS) & $0.1 \pm 0.1$ & $b$ & $4.4 \pm 1.2$ & c & $12.1 \pm 2.7$ & $a$ & $5.9 \pm 1.9$ & $c$ & $6.7 \pm 0.6 a$ & $b$ \\
\hline Total oxidised $\mathrm{N}$ (mg kg${ }^{-1}$ dry weight) & $2.41 \pm 1.28$ & $b$ & $0.08 \pm 1.00$ & $a$ & $0.07 \pm 0.07$ & $a$ & $0.11 \pm 0.16$ & $a$ & $0.37 \pm 0.27$ & c \\
\hline Ammonium (mg kg ${ }^{-1}$ dry weight) & $0.06 \pm 0.02$ & $b$ & $0.61 \pm 0.58$ & c & $0.92 \pm 0.44$ & $a$ & $0.34 \pm 0.25$ & $c d$ & $0.27 \pm 0.19$ & $d$ \\
\hline Total inorganic $\mathrm{N}$ ( $\mathrm{mg} \mathrm{kg}^{-1}$ dry weight) & $2.46 \pm 1.28$ & $a$ & $0.69 \pm 0.57$ & c & $0.99 \pm 0.47$ & $a b$ & $0.46 \pm 0.29$ & c & $0.64 \pm 0.32$ & $b c$ \\
\hline Bulk Density $\left(\mathrm{g} \mathrm{cm}^{-3}\right)$ & $1.30 \pm 0.13$ & $b$ & $0.84 \pm 0.21$ & c & $0.29 \pm 0.03$ & $a$ & $0.42 \pm 0.07$ & $a$ & $0.60 \pm 0.03$ & $d$ \\
\hline Organic matter content (\%) & $3.8 \pm 0.5$ & $b$ & $5.5 \pm 1.2$ & c & $21.8 \pm 4.6$ & $a$ & $5.5 \pm 1.3$ & c & $6.0 \pm 0.7$ & $c$ \\
\hline Humic substances (RAU $\mathrm{cm}^{-1}$ ) & $0.90 \pm 0.46$ & $b$ & $1.15 \pm 0.85$ & $b$ & $0.33 \pm 0.16$ & $a$ & $0.67 \pm 1.07$ & $a$ & $0.15 \pm 0.03$ & c \\
\hline Sodium ( $\mathrm{g} \mathrm{kg}^{-1}$ dry weight) & $0.02 \pm 0.01$ & $b$ & $4.18 \pm 1.57$ & c & $39.49 \pm 10.63$ & & $7.59 \pm 4.63$ & $e$ & $10.31 \pm 1.87$ & $d$ \\
\hline Potassium (g kg ${ }^{-1}$ dry weight) & $0.02 \pm 0.01$ & $b$ & $0.28 \pm 0.09$ & c & $1.75 \pm 0.31$ & $a$ & $0.58 \pm 0.29$ & $d$ & $0.64 \pm 0.13$ & $d$ \\
\hline Calcium (g kg ${ }^{-1}$ dry weight) & $0.07 \pm 0.05$ & $b$ & $0.24 \pm 0.09$ & c & $3.54 \pm 0.87$ & $a$ & $0.50 \pm 0.31$ & c & $0.63 \pm 0.08$ & $c$ \\
\hline Phosphate (mg kg ${ }^{-1}$ dry weight) & $3.42 \pm 1.76$ & $b$ & $1.95 \pm 0.35$ & c & $1.02 \pm 0.95$ & $a$ & $3.08 \pm 1.14$ & $b$ & $3.38 \pm 0.43$ & $b$ \\
\hline
\end{tabular}




$\begin{array}{lcccccccccccccc}\mathrm{C}(\%) & 1.7 \pm 0.3 & b & 2.2 \pm 0.4 & b & 9.7 \pm 2.4 & a & 2.4 \pm 0.7 & b & 2.2 \pm 0.3 & b \\ \mathrm{~N}(\%) & 0.17 \pm 0.03 & b & 0.21 \pm 0.03 & c & 0.72 \pm 0.17 & a & 0.23 \pm 0.05 & c & 0.25 \pm 0.03 & c \\ \text { C/N ratio } & 10.0 \pm 0.7 & b c & 10.5 \pm 0.8 & c & 13.5 \pm 0.7 & a & 10.0 \pm 1.3 & b c & 8.7 \pm 0.3 & b\end{array}$

554

555

556

557

558 
Table 2. Organic matter cycling measurements at all 5 sites. Gas flux site means $(n=12)$ are

560 presented \pm standard deviation. For carbon substrate mineralisation $\left({ }^{14} \mathrm{CO}_{2}\right.$ evolution $) \mathrm{n}=6$. The site

561 effect was evaluated using a linear mixed effects model. Significant differences $(p<0.05)$ between

562 site means are denoted by different letters. Non significant results are recorded as $n s(p>0.05)$.

563

\begin{tabular}{|c|c|c|c|c|c|c|c|c|c|c|}
\hline & \multicolumn{2}{|l|}{ Agricultural } & \multicolumn{2}{|l|}{ Restored } & \multicolumn{2}{|l|}{ Natural } & \multicolumn{2}{|l|}{ Restored } & \multicolumn{2}{|l|}{ Natural } \\
\hline & & & High & & High & & Low & & Low & \\
\hline $\mathrm{CO}_{2}$ flux $\left(\mathrm{mg} \mathrm{m}^{-2} \mathrm{~h}^{-1}\right)$ & $69.8 \pm 39.1$ & $a$ & $48.5 \pm 57.5$ & $a$ & $18.7 \pm 26.1$ & $a$ & $615.1 \pm 200.4$ & c & $264.6 \pm 117.8$ & $b$ \\
\hline $\mathrm{CH}_{4}$ flux $\left(\mathrm{mg} \mathrm{m}^{-2} \mathrm{~h}^{-1}\right)$ & $0.02 \pm 0.12$ & ns & $-0.01 \pm 0.04$ & ns & $-0.01 \pm 0.03$ & ns & $0.08 \pm 0.08$ & ns & $0.02 \pm 0.02$ & ns \\
\hline $\mathrm{N}_{2} \mathrm{O}$ flux $\left(\mathrm{mg} \mathrm{m}^{-2} \mathrm{~h}^{-1}\right)$ & $-0.02 \pm 0.04$ & ns & $0.00 \pm 0.06$ & ns & $-0.02 \pm 0.06$ & ns & $0.00 \pm 0.06$ & $n s$ & $-0.02 \pm 0.06$ & ns \\
\hline $\begin{array}{l}{ }^{14} \mathrm{CO}_{2} \text { evolution (\% evolved } \\
\text { of total }{ }^{14} \mathrm{C} \text {-substrate added) }\end{array}$ & $24.2 \pm 1.2$ & $b$ & $14.6 \pm 2.2$ & $a c$ & $12.3 \pm 1.1$ & $a$ & $19.9 \pm 2.8$ & $d$ & $16.3 \pm 2.4$ & c \\
\hline
\end{tabular}


564 Supplementary table 1 . Soil properties measured at all 5 sites by depth. Individual depth means by site $(n=6)$ are presented \pm standard deviation. Dry wt

565 indicates dry weight.

566

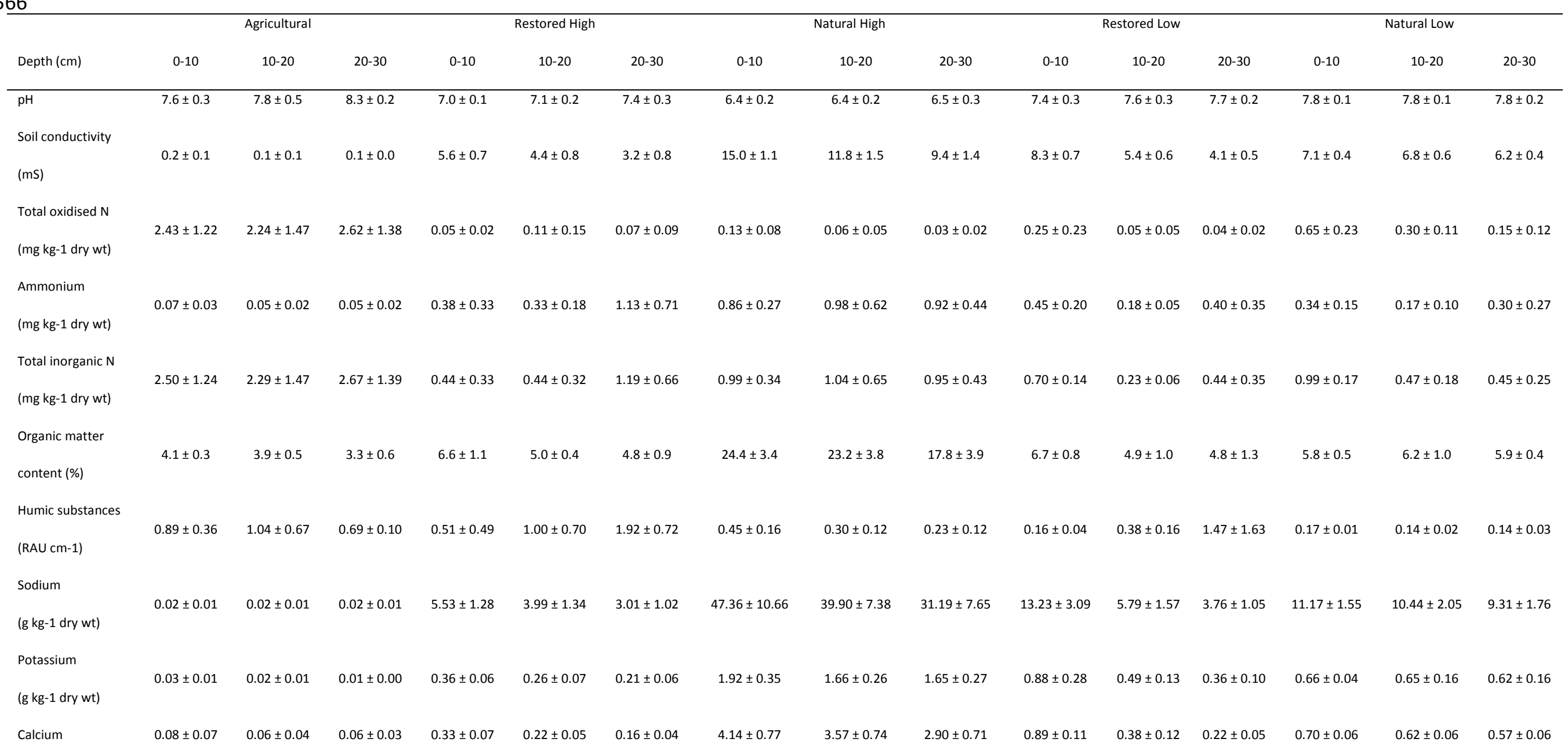


(g kg-1 dry wt)

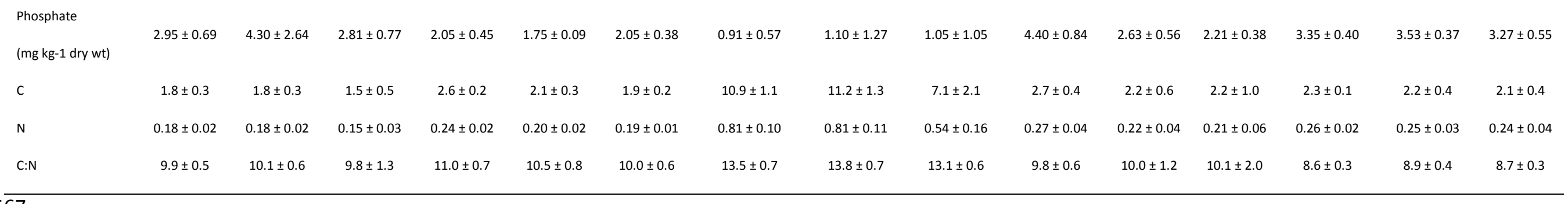

$5 \overline{67}$

568

569

570

571

572

573 